\title{
Regulatory T Cells in Patients with Idiopathic Thrombocytopenic Purpura
}

\author{
Idiyopatik Trombositopenik Purpura Olgularında Düzenleyici T Hücreler
}

\author{
Alev Akyol Erikçi, Bülent Karagöz, Oğuz Bilgi \\ Gülhane Military Medical Academy, Haydarpaşa Training and Research Hospital, Clinic of Hematology, Istanbul, Turkey
}

\section{Abstract}

Objective: Immune thrombocytopenic purpura (ITP) is an immunemediated bleeding disorder in which platelets are opsonized by autoantibodies and destroyed by an Fc receptor-mediated phagocytosis by the reticuloendothelial system within the spleen. Autoimmune processes are also considered in the pathogenesis of this disorder. CD4+CD25+FoxP3+ regulatory T (Treg) cells and CD8+CD28Treg cells have roles in autoimmune diseases. We investigated these regulatory cells in ITP patients.

Materials and Methods: We included 22 ITP patients and 16 age-matched healthy subjects. CD4+CD25+FoxP3+ Treg cells and CD8+CD28- cells were investigated by three-color flow cytometry. The ratios of these cell populations to total lymphocytes were calculated. Statistical analysis was carried out with the Mann-Whitney $U$ test.

Results: CD4+CD25+ Treg cells were $9.69 \pm 3.70 \%$ and $12.99 \pm 5.58 \%$ in patients with ITP and controls, respectively. CD4+CD25highFoxP3+ cells were $27.72 \pm 19.74 \%$ and $27.55 \pm 23.98 \%$ in ITP patients and controls, respectively. The percentages of both of these cell types were not statistically significant when compared to the control group.

Conclusion: We did not find any differences in ratios of CD4+CD25+FoxP3+ Treg cells or CD8+CD28- T cells in lymphocytes between patients and healthy subjects. We conclude that these circulatory cells are not different in ITP, but further studies are needed to explore the putative roles of these regulatory cells.

Keywords: Idiopathic thrombocytopenic purpura, Regulatory T cells

\section{III}

Amaç: İmmün trombositopenik purpura (ITP) trombositlerin otoantikorlar tarafından opsonize edildiği ve retiküloendotelyal sistem tarafından Fc reseptör aracılı fagositoz ile dalakta yıkıldığı immün kaynaklı bir kanama bozukluğudur. Bu bozukluğun patogenezinde otoimmün süreçler de sorumlu tutulmaktadır. CD4+CD25+Foxp3+ regulatuvar T (Treg) hücreleri ve $\mathrm{CD} 8+C D 28$ - Treg hücreler otoimmün hastalıklarda rol oynamaktadır. Çalışmamızda ITP'li hastalarda bu regülatuvar hücreleri araştırdık.

Gereç ve Yöntemler: ITP'li 22 hasta ile yaş uyumlu 16 sağlıklı birey dahil edildi. CD4+CD25+Foxp3+ Treg hücreler ve CD8+CD28- hücreler üç renkli akım sitometri ile çalışıldı. Bu hücre popülasyonunun tüm lenfositlere oranı hesaplanmıştır. İstatiktiksel değerlendirmede MannWhitney $U$ testi kullanılmıştır.

Bulgular: $C D 4+C D 25+$ Treg hücreler iTP'de ve kontrol grubunda $\% 9,69 \pm 3,70$ ve $\% 12,99 \pm 5,58$ saptandılar. CD4+CD25 yüksek FoxP3+ hücreler ise ITP'de ve kontrol grubunda \%27,72 $\pm 19,74$ ve $\% 27,55 \pm 23,9$ olarak saptandı. Her iki hücre tipi de kontrol grubu ile karşılaştırıldığında istatiktiksel olarak anlamlı bulunmamıştır.

Sonuç: Lenfositlerdeki CD4+CD25+Foxp3+ Treg hücreler ve CD8+CD28- T hücrelerdeki oranlarında fark bulamadık. Biz çalışmamızda ITP'de dolaşan regulatuvar hücrelerde fark bulamadık ama daha geniş kapsamlı çalışmalara ihtiyaç vardır.

Anahtar Sözcükler: İdiopatik trombositopenik purpura, Düzenleyici T hücreleri

\section{Introduction}

Immune thrombocytopenia (ITP) is an autoimmune bleeding disorder in association with increased platelet destruction and impaired platelet production. It is mediated by $\lg G$ antiplatelet autoantibodies in which the targets are platelet membrane glycoproteins (GPs), such as GPIIb/IIla and GPIb/IX. CD4+CD25+ regulatory $\mathrm{T}$ (Treg) cells and CD8+CD28- $\mathrm{T}$ lymphocytes have major roles in self-tolerance. To maintain the immune tolerance and to prevent autoimmune disease, CD4+CD25+FoxP3+ Treg cells, CD4+ T cells with high expression of CD25, and transcription factor forkhead box P3 (FoxP3), also referred to as FoxP3 regulatory $\mathrm{T}$ cells, play an important role. Treg cells account for approximately $5 \%$ of circulating CD4+ T cells. Decreased numbers of Treg cells have been reported in patients with various autoimmune diseases, including ITP, rheumatoid arthritis, and systemic lupus erythematosus $[1,2,3,4,5]$. 
In the case of Treg deficiency, peripheral tolerance can fail, leading to the development of autoimmunity. The purpose of this study was to evaluate Treg cells in previously untreated newly diagnosed ITP cases.

\section{Materials and Methods}

\section{Flow Cytometry}

Peripheral blood samples were obtained and studied while still fresh. Flow cytometry was used to count CD4+CD25+ Treg cells and CD8+CD28- suppressive cells. Flow cytometry was performed on a Becton Dickinson FACSCalibur. Data were obtained and analyzed using CellQuest software.

\section{Monoclonal Antibodies}

Antihuman monoclonal antibodies conjugated with fluorochromes and appropriate isotype controls were used: fluorescein isothiocyanate (FITC) conjugated anti-CD28 (BD Pharmingen Catalog No: 555728), anti-CD4 (Caltag Laboratories Catalog No: MHCD0401), phycoerythrin-cyanine 5 (PC5) conjugated anti-CD8 (eBioscience Catalog No: 15-0088), antiCD25 (BD Pharmingen Catalog No: 555433), and phycoerythrin (PE) conjugated anti-FoxP3 (eBioscience Catalog No: 12-4776).

\section{Cell Preparation and Surface Staining}

Human peripheral blood mononuclear cells were isolated using Histopaque (Sigma Catalog No: 1077) gradient centrifugation. Aliquots of $100 \mu \mathrm{L}$ were transferred to polypropylene test tubes (12x75 mm; BD Bioscience Catalog No: 352052) and $20 \mu \mathrm{L}$ of conjugated monoclonal antibodies or isotype controls was added to each tube. Flow cytometric analysis was performed by BD FACSCalibur after the appropriate staining protocol.

\section{FoxP3 Staining}

CD4 and CD25 surface staining was carried out. The CD4+CD25 tube was then washed with cold PBS and resuspended, $1 \mathrm{~mL}$ of freshly prepared fixation/permeabilization working solution was added, and the tube was incubated at $4{ }^{\circ} \mathrm{C}$ for $30-60 \mathrm{~min}$ in the dark and washed twice by adding $2 \mathrm{~mL}$ of $1 \mathrm{X}$ permeabilization buffer. Next, $20 \mu \mathrm{L}$ of PE conjugated antihuman FoxP3 antibody in $1 \mathrm{X}$ permeabilization buffer was added and the tube was incubated at $4{ }^{\circ} \mathrm{C}$ for 30 min in the dark. Washing was repeated twice with $2 \mathrm{~mL}$ of $1 \mathrm{X}$ permeabilization buffer. After resuspension, analysis was performed by flow cytometry.

\section{Analysis}

CD8+CD28- cell percentages were evaluated using antiCD28/anti-CD8 double staining in lymphocyte-gated cells. CD8+CD28- cells, CD8+CD28+ cells, and the ratio of these cells were calculated.
Anti-CD4/anti-FoxP3/anti-CD25 triple staining was uved for CD4+CD25+ Treg cell counts. CD4+CD25high lymphocytes were gated and then CD4+CD25highFoxP3+ cells were calculated in CD4/FoxP3 histograms.

\section{Statistical Analysis}

Statistical analysis was performed using SPSS. The MannWhitney $U$ test was used to investigate immunological parameters of ITP patients and for comparisons with data of healthy subjects.

\section{Results}

We enrolled 22 previously untreated patients newly diagnosed with ITP (19 males, 3 females) and 16 age-matched controls (13 males, 3 females). All of the patients were admitted to our outpatient clinic. Thrombocytopenia was newly detected and they had received no previous treatment. The patients were investigated for possible causes of thrombocytopenia. Viral serology and other underlying autoimmune diseases were screened. Demographic findings are illustrated in Table 1. We performed bone marrow aspiration and biopsy in the relatively elderly patients (patients numbers 5, 9, and 17). No pathological findings such as dysplasia were detected. Findings were consistent

\begin{tabular}{|c|c|c|c|}
\hline Patient number & Age & Sex & $\begin{array}{l}\text { Platelets } \\
\text { (x109/L) }\end{array}$ \\
\hline 1 & 22 & Male & 19 \\
\hline 2 & 19 & Male & 34 \\
\hline 3 & 21 & Male & 58 \\
\hline 4 & 32 & Male & 46 \\
\hline 5 & 51 & Female & 22 \\
\hline 6 & 21 & Male & 18 \\
\hline 7 & 22 & Male & 65 \\
\hline 8 & 27 & Male & 42 \\
\hline 9 & 61 & Male & 31 \\
\hline 10 & 20 & Male & 52 \\
\hline 11 & 21 & Male & 37 \\
\hline 12 & 37 & Male & 16 \\
\hline 13 & 22 & Male & 88 \\
\hline 14 & 34 & Male & 49 \\
\hline 15 & 21 & Male & 23 \\
\hline 16 & 39 & Male & 76 \\
\hline 17 & 64 & Female & 35 \\
\hline 18 & 42 & Female & 79 \\
\hline 19 & 21 & Male & 17 \\
\hline 20 & 22 & Male & 29 \\
\hline 21 & 19 & Male & 53 \\
\hline 22 & 25 & Male & 27 \\
\hline
\end{tabular}


with ITP, including normal or increased megakaryocytes.

CD4+CD25+ Treg cells and CD4+CD25highFoxP3+ cells were calculated in lymphocytes. CD4+CD25+ Treg cells were $9.69 \pm 3.70 \%$ and $12.99 \pm 5.58 \%$ in patients with ITP and controls, respectively. CD4+CD25highFoxP3+ cells were $27.72 \pm 19.74 \%$ and $27.55 \pm 23.98 \%$ in ITP patients and controls, respectively. Both of these cell counts were not statistically different between groups.

We also detected no statistically significant difference in CD8+CD28- suppressor cells between ITP patients and controls $(12.50 \pm 9.40 \%$ and $11.77 \pm 4.64 \%$, respectively).

\section{Discussion}

Treg cells suppress effector $\mathrm{T}$ cell activation, which leads to induction of immune tolerance [6]. For this reason it is assumed that failure of the regulatory $\mathrm{T}$ cell system may induce autoimmunity $[7,8,9]$.

There are increasing numbers of studies demonstrating that decreased frequency of Treg cells has a role in ITP. Liu et al. reported that the percentage of Treg cells was significantly decreased in ITP patients with active disease in which no remission was achieved [10]. Sakakura et al. reported variations in Treg amounts according to platelet counts. In patients with low platelet counts there was no reduction in the percentage of Treg cells when compared to those with platelet counts over $100,000 / \mu \mathrm{L}$ [11]. In the study by Yu et al., defective circulating CD25 Treg cells were detected in patients with chronic ITP [12].

However, there are also studies that failed to detect any differences in Treg frequencies of patients with ITP compared to healthy controls $[13,14]$.

Similar to our results, Mazzucco et al. detected no significant difference between Treg cell and platelet counts in patients with ITP and the control group [15].

In our study we investigated previously untreated newly diagnosed ITP patients. We detected no significant difference in Treg cell frequencies in ITP patients and controls. We think that further studies are needed to explore the putative roles of these regulatory cells, especially in terms of long-term follow-ups and response to treatments.

\section{Ethics}

Informed Consent: It was taken.

\section{Authorship Contributions}

Concept: Alev Akyol Erikçi; Design: Alev Akyol Erikçi; Data Collection or Processing: Bülent Karagöz, Oğuz Bilgi, Alev Akyol
Erikçi; Analysis or Interpretation: Bülent Karagöz, Literature Search: Bülent Karagöz, Oğuz Bilgi, Alev Akyol Erikçi; Writing: Alev Akyol Erikçi, Bülent Karagöz.

Conflict of Interest: The authors of this paper have no conflicts of interest, including specific financial interests, relationships, and/or affiliations relevant to the subject matter or materials included.

Financial Disclosure: Contribution of the Turkish Society of Hematology.

\section{References}

1. Cines DB, Blanchette VS. Immune thrombocytopenic purpura. N Engl J Med 2002;346:995-1008.

2. Semple JW, Freedman J. Increased antiplatelet T helper lymphocyte reactivity in patients with autoimmune thrombocytopenia. Blood 1991;78:2619-2625.

3. Kuwana M, Kaburaki J, Ikeda Y. Autoreactive T cells to platelet GPIlb-IIla in immune thrombocytopenic purpura: role in production of anti-platelet autoantibody. J Clin Invest 1998;102:1393-1402.

4. Ogawara $H_{1}$ Handa $H$, Morita $K$, Hayakawa $M$, Kojima J, Amagai $H$, Tsumita $Y$, Kaneko Y, Tsukamoto N, Nojima Y, Murakami H. High Th1/Th2 ratio in patients with chronic idiopathic thrombocytopenic purpura. Eur J Haematol 2003;71:283288.

5. Semple JW, Milev Y, Cosgrave D, Mody M, Hornstein A, Blanchette V, Freedman $J$. Differences in serum cytokine levels in acute and chronic autoimmune thrombocytopenic purpura: relationship to platelet phenotype and antiplatelet T-cell reactivity. Blood 1996;87:4245-4254.

6. Itoh M, Takahashi T, Sakaguchi N, Kuniyasu Y, Shimizu J, Otsuka F, Sakaguchi S. Thymus and autoimmunity: production of CD25+CD4+ naturally anergic and suppressive $T$ cells as a key function of the thymus in maintaining immunologic self-tolerance. J Immunol 1999;162:5317-5326.

7. Nugent DJ. Immune thrombocytopenic purpura of childhood. Hematology 2006;2006:97-103.

8. Cruvinel WM, Mesquita D Jr, Araujo JAP, Salmazi KC, Kallas EG, Andrade LEC. Natural regulatory T cells in rheumatic diseases. Rev Bras Reumatol 2008;48:342355.

9. Sakaguchi S, Ono M, Setoguchi R, Yagi H, Hori S, Fehervari Z, Shimizu J, Takahashi T, Nomura T. Foxp3+CD25+CD4+ natural regulatory $T$ cells in dominant selftolerance and autoimmune disease. Immunol Rev 2006;212:8-27.

10. Liu B, Zhao H, Poon MC, Han Z, Gu D, Xu M, Jia H, Yang R, Han ZC. Abnormality of $\mathrm{CD} 4{ }^{+} \mathrm{CD} 25^{+}$regulatory $T$ cells in idiopathic thrombocytopenic purpura. Eur J Haematol 2007;78:139-143.

11. Sakakura M, Wada H, Tawara I, Nobori T, Sugiyama T, Sagawa N, Shiku H. Reduced $\mathrm{Cd} 4+\mathrm{Cd} 25+\mathrm{T}$ cells in patients with idiopathic thrombocytopenic purpura. Thromb Res 2007;120:187-193.

12. Yu J, Heck S, Patel V, Levan J, Yu Y, Bussel JB, Yazdanbakhsh K. Defective circulating CD25 regulatory $T$ cells in patients with chronic immune thrombocytopenic purpura. Blood 2008;112:1325-1328.

13. Andersson $P O$, Stockelberg $D$, Jacobsson $S$, Wadenvik $H$. A transforming growth factor- $\beta 1$-mediated bystander immune suppression could be associated with remission of chronic idiopathic thrombocytopenic purpura. Ann Hematol 2000;79:507-513.

14. Nishimoto T, Kuwana M. CD4+CD25+Foxp3+ regulatory $T$ cells in the pathophysiology of immune thrombocytopenia. Semin Hematol 2013;50(Suppl 1):S43-S49.

15. Mazzucco $K L$, Junior $L M$, Lemos NE, Wieck $A$, Pezzi $A$, Laureano $A M$, Amorin $B$, Valim V, Silla L, Daudt LE, Marostica PJ. Assessment of regulatory T cells in childhood immune thrombocytopenic purpura. ISRN Hematol 2013;2013:143687. 